\title{
Research Paper: Examining the Effective Factors on Villagers' Tendency to Retrofit Rural Housing in Iran
}

Aliakbar Anabestani ${ }^{{ }^{*}}$, Mojtaba Rousta ${ }^{2}$, Seyyed Mostafa Hedayatnejad Kashi' ${ }^{2}$, Tina Esmaieli ${ }^{3}$

1. Professor, Department of Geography, Faculty of Letters \& Humanities, Ferdowsi University of Mashhad, Mashhad, Iran.

2. Sistan \& Baluchestan University, Sistan \& Baluchestan, Iran.

3. Nour Branch, Islamic Azad University

\section{Article info:}

Received: 17 Jan. 2020

Accepted: 26 Apr. 2020

Keywords:

Villagers, Retrofitting, Rural Homes, Iran
Citation: Anabestani, A., Rousta, M., Hedayatnejad Kashi, S.M., \& Esmaieli, T. (2020). Examining the Effective Factors on Villagers' Tendency to Retrofit Rural Housing in Iran. Journal of Sustainable Rural Development, 4(2), 163-176. https://doi. org/10.32598/JSRD.4.2.5

https://doi.org/10.32598/JSRD.4.2.5 


\section{Introduction}

H

umans and their environment, at macro and micro levels, are interrelated. While humans are enjoying the power of adjusting to environmental circumstances, they are continuously trying to form and change their surrounding environment and this change appears in their housing (Seidaee et al., 2010: 49). Housing is one of the most important issues that humans have always dealt with and tried to solve this problem and find a reasonable and appropriate answer to it (Jamshidi et al., 2013: 70).

In international laws, particularly in the 11th article of international treaty of economic, social and cultural laws, the right to having good housing and a life with human respect is considered as one of the basic needs and a key index for each person and family (Frimpong, 2001: 1). It is related to the dwellers' life quality improvement (Young, 2007: 4; Maliene, 2008: 5). Compared with other goods, housing can be considered as the basic factor of both social inequity and cooperation (Bayesten \& Darz, 1998: 296). This is due to some features such as being irreplaceable, being a capital, being durable and costly and being immovable (Gallent \& Robinsin, 2011: 298).

In fact, after the occurrence of natural events (even on small scale), some issues such as attrition of rural textures, using unstandardized and unstable building materials, and failing to observe technical and engineering principles in construction and lack of adaptation to the environment are considered as the basic reasons for many human and financial casualties in rural areas (Fal Soleiman, 2012: 77). On the one hand, due to failure to observe technical and safety principles in building homes in the past and on the other hand, lack of adaptation of these homes to today's needs of our rural society, the villagers have begun to make changes in rural homes and make them similar to urban homes (Anabestani, 2014: 60 ). Regarding the importance of this subject, the government has been charged with implementing the plan to increase the quality of rural homes according to the law of the Fourth Development Plan and budgetary rules of Housing Foundation of Islamic Revolution.

This plan includes a series of practices in rural areas, such as developing a rural technical system, issuance of planning permission, educating rural bricklayers, renovating rural homes, rural housing bank facilities and restructuring homes damaged by natural events. Most of the works have been done as planned and with the aim of achieving quantitative objectives in retrofitting rural buildings and increasing the number of stable dwelling units in rural areas (Shakuri \& Asgari, 2012: 151). In other words, finally, these problems forced the officials to consider solving them. One of these solutions is paying credit to the rural societies in the fields of skeletal development, housing patterns and housing retrofitting. In other words, one of the government-based credits that is paid to the villagers is the credit for rural housing retrofitting (Anabestani et al., 2012: 64). Given the importance of these programs in improving rural housing retrofitting, particularly in Jahrom County (Simckan District), our main research question is "what are the most effective factors on villagers' tendency to retrofit rural housing?'

Then, with the hypothesis of "it seems that using rural housing facilities has a significant effect on villagers' tendency to retrofit rural homes", we analyze the data.

\section{Literature Review}

\section{Rural housing}

In the real world, the village is a unified phenomenon in which we cannot separate cultural, economic, social and environmental components and factors from each other (Anabestani, 2014: 58). Housing in the villages not only is a dwelling but also is important for rural families in terms of production and employment (Anabestani, 2011: 101). It should be noted that Iran is prone to having earthquakes and from time to time, severe earthquakes occur in this country. In recent decades, earthquakes have led to heavy damages and disasters. In the past decade, eight major earthquakes in Iran have left thousands of people homeless (Amirahmadi, 1992). One of the important domains vulnerable to earthquakes is rural buildings. Most of them lack minimum retrofitting standards and so, housing renovation and retrofitting are considered in the countries' macro-plans.

According to Housing Foundation statistics and data, about 1,700,000 rural residential units were renovated and reconstructed with the government support by late 2008 (Housing Foundation of Islamic Revolution, 2008). In most developing countries, planners have not paid enough attention to skeletal development and retrofitting of rural housing that has led to paying insufficient attention by rural home builders to the formal structural codes in the regions prone to earthquakes due to economic and financial reasons and poor control by local associations (Lewis, 2003: 34). Besides, these regions are highly vulnerable to earthquakes due to insufficiency of 
necessary infrastructure (Young, 2007: 4). Thus, the first step in the revival of the country's villages is the renovation of rural housing (Ghadiri Masoum \& Akbarpur SaraKanrud, 2011: 74).

\section{Rural housing credits}

Since the beginning of rural life, financial credits have been in the rural society. Rural families have used credits for their production, agricultural and consumption needs (Taleb, 1993: 54). Providing micro-loans to rural families with various income levels is based on a vast range of building activities and housing procurement such as house repairs, restructuring and renovating of the present physical structure, acquisition of land, building a new house and even improving the present sub-structural facilities like sewage system (Kumar \& Newport, 2007: 2). Mostly, according to the process of "step-by-step building" which means accepting local officials and engineers' supervision by the owners, these credits are put at their disposal. So, providing the necessary credits for retrofitting rural housing in developing countries typically includes part of rural credits which are mostly paid by finance companies such as banks, local credit unions, cooperatives, etc. (Einali et al., 2014: 79 from Douglas, 2003; Khan et al., 2009: 2; Grameen Bank, 2011). In Iran, credits for retrofitting rural housing have been paid under government's support and by commercial banks since 2005 and following "rural housing renovation" plan which started in 1995 by the Housing Foundation of Islamic Revolution in order to promote safety, health and welfare of villagers. Due to the mentioned features, rural housing loan has positive and negative outcomes, in terms of different economic, social, skeletal and environmental aspects, and effects on villagers' life and their environment (Ghasemi
Aerahaee \& Rostamalizedeh, 2012: 69). Despite all the mentioned shortcomings of the rural housing sector, focusing on rural housing has been disregarded and few credits have been allocated to this sector. Rural housing credits were organized and presented in the Fourth Development Plan, but they were not acceptably implemented due to banks' unwillingness to loan villagers or villagers' inability to introduce a guarantor to the bank. Due to their economic conditions, most villagers face difficulties in securing this cost. Regarding poor economic conditions of villagers in building a stable house, the necessity of investment and giving credits for rural housing by the government is felt. Economic conditions in the country's villages do not allow villagers to build a house according to standard principles and so, the government's financial policies in the housing sector should be focused on this issue. In our country, land acquisition policies for building, financial securing, creating cooperatives and supporting housing should be considered as some strategies for housing procurement for the needy (Motiee Langerudi \& Bakhshi, 2005: 36).

\section{Rural housing retrofitting}

Rural development and rural housing retrofitting are always considered as two most important concerns of governors and rural planners (Beiti, 2012: 115). One of the plans for rural development in the Fourth Development Plan is the national plan of rural housing retrofitting which has already been started. Housing retrofitting credits are paid to the villagers in order to achieve some goals such as building stable houses, providing houses proportionate to the villagers' needs, preserving the identity and public appearance of villages and the like.

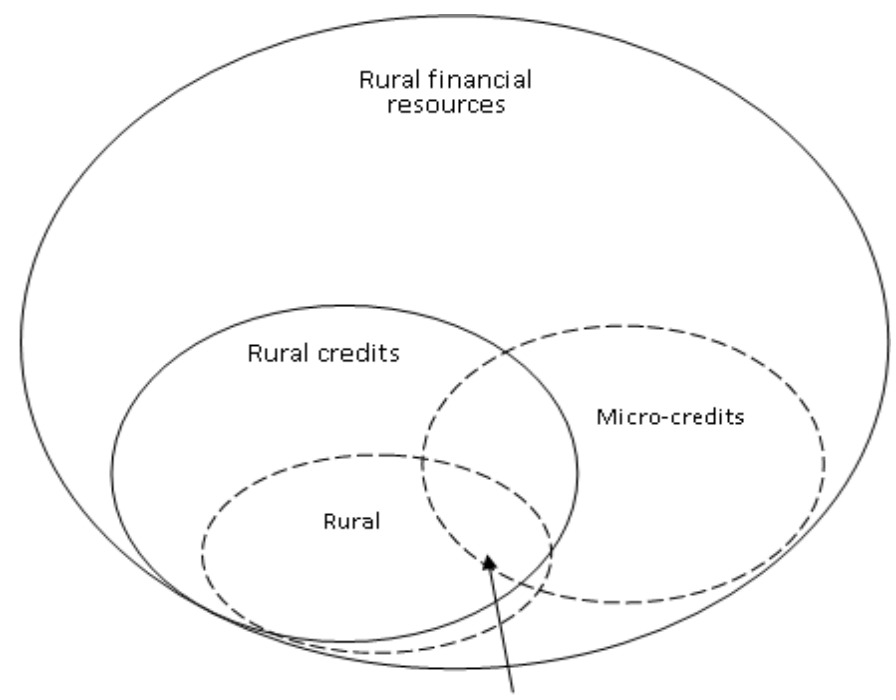

Figure 1. The status of rural housing credits within the rural financial resources system. Source: GGAP, 2003 
Unacceptable quality and high vulnerability of rural houses due to using low-quality materials, unsuitable location and other factors annually impose large disbursements on rural families and society (Motiee Langerudi \& Bakhshi, 2010: 37). Housing retrofitting is one of the important preventive measures within the crisis management cycle. Prevention is the process of programming and performing such measures which reduce natural disaster-based risks (Dehghan Faruji, 2010: 2). Rural housing retrofitting is one of the important issues in improving the life quality of villagers and preventing possible damages at the time of natural disasters. So, rural housing retrofitting is considered as one of the main bases of the Housing agenda (Mahdavinezhad, 2014: 39). Although Housing Foundation of Islamic Revolution has strongly focused on rural housing retrofitting since 2005, most rural areas lack appropriate and quality housing (Anabestani et al., 2012: 63). Lack of retrofitting of rural houses against natural disasters such as earthquakes, floods and storms is very important. Using low-quality materials and failing to observe technical regulations in the building has an effective role (Rezvani, 2011: 143). Most villages are more vulnerable than cities because of infrastructural reasons such as low knowledge, economic and cultural poverty and lack of supervision over rural building. Rural housing retrofitting is a method for reducing the rate of human casualties and economic damages in rural regions (Dehghan Faruji, 2010: 4).

Background Review
In the field of rural housing retrofitting, there are many important projects. We mention the following cases (Table 1).

Research conducted so far has been focused on the use of housing credits and its impact on the development of rural settlements and especially on its physical fabric. However, so far, no studies have been conducted on the tendency of villagers to use rural housing credits. Therefore, the present study can offer a new perspective in this area.

\section{Methodology}

Our research method is descriptive-analytic, and it is of applied-development type. The research area, Simekan district in Jahrom County, has 39 villages with a population of 17241 persons. Our statistical population includes 11 villages of Simekan District in the suburbs of Jahrom County. These villages have taken a loan of over 50 items from the Housing Foundation (Table 2). For estimating the sample population at the rural family level, by using the Cochran sampling method with 95 percent accuracy, 186 persons (Family guardian) were questioned by simple random sampling method. We used a questionnaire for gathering information which was then analyzed with SPSS and Excel software. In addition, we used the explorative-factorial analysis method for analyzing the effective factors on rural housing retrofitting. Therefore, the result was reducing 7 initial factors into 2 superior factors by Varimax Rotation.

Table 1. Some studies on our research topic

\begin{tabular}{|c|c|}
\hline Researcher & Results \\
\hline Sartippipour (2005) & $\begin{array}{l}\text { Based on examining the sampling plan data of rural housing features of } 2003 \text {, he firstly evaluated the province's rural } \\
\text { housing status in } 4 \text { fields, including strength conditions (safety), enjoyment (comfort), economic conditions (livelihood } \\
\text { function and economic role) and environment and damages resulting from the housing. Then he proposed some sug- } \\
\text { gestions for policy - making in order to solve the current problems. }\end{array}$ \\
\hline $\begin{array}{l}\text { Rahmani Fazli \& Kavyani } \\
\text { (2009) }\end{array}$ & $\begin{array}{l}\text { In terms of "Effectiveness of micro-credits in rural housing renovation of Saghez County", they found that credits for } \\
\text { renovating rural housing in the studied area were effective and studied the most effective credits in the field of housing } \\
\text { retrofitting within the studied area. }\end{array}$ \\
\hline $\begin{array}{l}\text { Karimi Azar \& Shamsi } \\
\quad \text { Yousefi (2009) }\end{array}$ & $\begin{array}{l}\text { For constructing in a rural context, the best options are using new materials in combination with the available useful } \\
\text { and acceptable materials within the area and using new technologies. }\end{array}$ \\
\hline Seidaee et al. (2010) & $\begin{array}{c}\text { The central district of Buyerahmad is at one level, and Pataveh, central Gachsaran and central Kohgiluyeh are at the } \\
\text { other level and Kabgian, central Bahmaee, Landeh, Central Dena, Sarfaryab, Cheram, Basht, Lodab, Dishmun, Charusa, } \\
\text { tropical Bahmaee and Margun are at the next homogenous level. }\end{array}$ \\
\hline $\begin{array}{l}\text { Motiee Langerudi \& } \\
\text { Bakshi (2010) }\end{array}$ & $\begin{array}{l}\text { Paying housing credits both increases villagers' ability and satisfaction in the field of housing and is effective in keeping } \\
\text { the population in the villages. }\end{array}$ \\
\hline Saeedi \& Amini (2010) & $\begin{array}{l}\text { Economic-social changes and human mobility have led to stability/instability trends and spatial-skeletal changes in rural } \\
\text { housing. Thus, rural-urban movement and leaving some buildings in villages have led to a functional change in using } \\
\text { internal spaces of houses. }\end{array}$ \\
\hline $\begin{array}{l}\text { Shamsoddini \& Rostami } \\
\text { (2011) }\end{array}$ & $\begin{array}{l}\text { In } 24 \text { villages of Mamsani County, apart from comfort, safety and good appearance, rural housing renovation showed a } \\
\text { negative effect on villagers' living economy. }\end{array}$ \\
\hline $\begin{array}{l}\text { Ghasemi Ardahaee \& } \\
\text { Rostamalizadeh (2011) }\end{array}$ & $\begin{array}{l}\text { The results show that rural housing loan has some positive and negative outcomes and a series of skeletal, social, } \\
\text { economic and cultural effects on villagers' lifestyles. }\end{array}$ \\
\hline
\end{tabular}


Table 1. Some studies on our research topic

\begin{tabular}{|c|c|}
\hline Researcher & Results \\
\hline $\begin{array}{l}\text { Afrakhteh \& Havasi } \\
\text { (2011) }\end{array}$ & $\begin{array}{l}\text { Rural housing loan policy has not resulted in full success, because it has not been presented in a comprehensive sys- } \\
\text { tematic rural development plan which is matched with strengthening objectives. }\end{array}$ \\
\hline Anabestani et al. (2012) & $\begin{array}{l}\text { In terms of housing pattern changes in the area, some strategies for retrofitting rural housing are suggested by using lo- } \\
\text { cal architectural patterns, appropriate floor area for the renovated dwelling units and paying attention to rural building } \\
\text { patterns for achieving appropriate and quality housing. }\end{array}$ \\
\hline \multicolumn{2}{|l|}{$\begin{array}{l}\text { Mohammadi Yeganeh et } \\
\text { al. (2013) }\end{array}$} \\
\hline Anabestani (2014) & $\begin{array}{l}\text { Some strategies were suggested, such as focusing on villagers' social interactions in building new houses, relying on } \\
\text { local and racial culture, reducing the dependence on the towns surroundings in building rural houses. }\end{array}$ \\
\hline Einal et al. (2014) & $\begin{array}{l}\text { The results show a significant difference in the effectiveness of skeletal components in reducing housing damages } \\
\text { between, before and after using housing credits. }\end{array}$ \\
\hline Azimi et al. (2014) & $\begin{array}{l}\text { The results show an improvement in the physical quality of buildings and reflect some changes in rural lifestyles in } \\
\text { recent years. }\end{array}$ \\
\hline Rezvani et al. (2014) & $\begin{array}{l}\text { The results show that there is a difference in the villagers' need for the housing loan and their demand for receiving } \\
\text { the loan between central and suburban dwellings, such that about } 80 \text { percent of applicants for rural housing loans } \\
\text { belonged to two dwellings of "Varavi " ( center of district ) and " Khuzi " (center of rural district). }\end{array}$ \\
\hline Boshagh et al. (2014) & The results show that there is a difference between rural types in dimensions and indices of housing stability. \\
\hline $\begin{array}{l}\text { Farhadi Quliyanlou } \\
\qquad(2016)\end{array}$ & $\begin{array}{c}\text { Studies show that the implementation of this special plan to improve rural housing has disrupted the texture and } \\
\text { architecture of villages. }\end{array}$ \\
\hline $\begin{array}{l}\text { Mohammadi Yeganeh et } \\
\text { al. (2017) }\end{array}$ & $\begin{array}{l}\text { Findings show that there is a significant relationship between the sense of security of rural households and its dimen- } \\
\text { sions before and after receiving the house strengthening credits. }\end{array}$ \\
\hline Rabet et al. (2017) & $\begin{array}{l}\text { The results of this study indicate that the financial facilities for rural housing have played an important role in creating } \\
\text { physical changes in rural housing of rural settlements that have used these facilities. }\end{array}$ \\
\hline Riahi et al. (2017) & $\begin{array}{l}\text { According to data, one can suggest that housing bank facilities have had an effective role in the social dimension of } \\
\text { rural development. Because the overall weight for this dimension and profile was } \% 75 \text { and all indexes in this aspect had } \\
\text { a high percentage. }\end{array}$ \\
\hline Faezi et al. (2018) & $\begin{array}{l}\text { The results of the first test showed that some of the criteria related to performance indicators and aesthetics are zoning } \\
\text { height, the proportion in the building, compliance with the settled units, compliance with the structure and the execu- } \\
\text { tive management and oversight of the village, in the } 99 \% \text { of variables, and appearance of the furniture, flexibility and } \\
\text { readability of buildings, spatial unity and consistency of building styles, harmony between form, at } 95 \% \text {, which indicates } \\
\text { that the strengthening effect is significant. }\end{array}$ \\
\hline $\begin{array}{l}\text { Ghadiri Masoum et al. } \\
\text { (2021) }\end{array}$ & $\begin{array}{l}\text { The results of the t-test on the hypothesis indicate its significance and the negative effect of housing renovation on the } \\
\text { participation rate of women in economic activities so that with a significant level of } 0.000 \text {, the coefficient of the t-test } \\
\text { is equal to 9.742- that confirms the hypothesis of the effect of housing renovation, and changing the functions of rural } \\
\text { housing emphasizes the level of women's participation in economic activities. }\end{array}$ \\
\hline
\end{tabular}

Table 2. The number of loan taker families and performance of technical supervisors and distribution of planning permission issuance in our sample villages during 2005-2016.

\begin{tabular}{|c|c|c|c|c|c|c|c|c|}
\hline \multirow{2}{*}{$\begin{array}{c}\text { Row } \\
1\end{array}$} & \multirow{2}{*}{$\begin{array}{c}\text { Village Name } \\
\text { Arjuyeh }\end{array}$} & \multirow{2}{*}{$\begin{array}{c}\text { Distance of the } \\
\text { nearest town }\end{array}$} & \multicolumn{4}{|c|}{$\begin{array}{l}\text { Number of buildings being construct- } \\
\text { ed since } 2005\end{array}$} & \multirow{2}{*}{$\begin{array}{c}\text { Number of buildings with } \\
\text { supervisor }\end{array}$} & \multirow{2}{*}{$\begin{array}{c}\begin{array}{c}\text { Number of loan } \\
\text { taker families }\end{array} \\
300\end{array}$} \\
\hline & & & 278 & 47 & 14 & 339 & & \\
\hline 2 & Shaghun & 15 & 101 & 23 & 19 & 143 & 124 & 113 \\
\hline 3 & Mazcan & 17 & 59 & 4 & 3 & 66 & 63 & 62 \\
\hline 4 & Kushcar & 2 & 47 & 6 & 6 & 59 & 53 & 53 \\
\hline 5 & Behjan & 30 & 82 & - & 16 & 98 & 82 & 85 \\
\hline 6 & Kalakeli & 13 & 41 & 10 & 3 & 54 & 51 & 47 \\
\hline 7 & Jarmasht Bala & 40 & 121 & 34 & 4 & 159 & 155 & 130 \\
\hline 8 & Esfanjan & 37 & 80 & - & 4 & 84 & 80 & 93 \\
\hline 9 & Dashtdal & 30 & 56 & 5 & 2 & 63 & 61 & 62 \\
\hline 10 & Chartagh & 33 & 49 & 7 & 1 & 57 & 56 & 53 \\
\hline 11 & Gudzaa & 3 & 63 & 5 & 4 & 72 & 68 & 68 \\
\hline Total & - & & 977 & 141 & 76 & 1194 & 1118 & 1066 \\
\hline
\end{tabular}

Source: Housing Foundation of Islamic Revolution of Jahrom County, 2019, and authors' calculations. 
In the present research, we used the content validity method for increasing the research validity (Hooman, 1997: 228). Accordingly, the questionnaire was presented to authorities, experts and university professors and after collecting their views, the necessary corrections were made. We used the Cronbach alpha coefficient for determining research reliability. The calculated alpha was 0.782 , which is an acceptable value; thus, we can say that we used the necessary precision for ensuring the reliability of structures in the questionnaire and the designed items for assessing the variables are internally correlated (Table 3 ).

Our under study area, Simekan District, Jahrom County in Fars province, has 40 villages, 3741 families with a population of 17241 persons, and agriculture is considered as the most important activity of this area. This district is limited to the north by Khafar, to the east by central district, and to the west by Firuzabad County and to the south by Ghirocarzin County. Its area is $942.5 \mathrm{~km} 2$, which equals 16.5 percent of the total area of Jahrom County (Simekan District, 2010; Anabestani \& Rusta, 2012: 68).

\section{Findings}

\section{Respondents' individual characteristics}

In terms of gender identity, 133 persons (71\%) are male and $53(29 \%)$ are female. In terms of education, 28/4 percent of subjects have elementary education, 13 percent of them have middle education, $42.6 \%$ have secondary education and 16 percent of them have an associate degree or higher.

Furthermore, in terms of ownership type, 10.2 percent of houses have formal ownership documents, 84.2 per- cent of them have a preliminary agreement and 5.6 percent of them are rental. In terms of respondents' jobs, 47.3 percent of them are farmers, 29.03 percent of them are workers and others have other jobs. 83 percent of buildings are 1-5 years old and 17 percent of them are 6-10 years old. In terms of quality, 92 percent of houses are new and 83 percent of them belong to a single family (Table 4).

In terms of the area of residential units, about 80 percent of them are $100 \mathrm{~m}^{2}$. In terms of the area of the total foundation, nearly 80 percent of houses are $100 \mathrm{~m}^{2}, 10$ percent of them are over $100 \mathrm{~m}^{2}$ and 10 percent of them are less than $100 \mathrm{~m}^{2} .95$ percent of residential units are villas and 5 percent of them have two floors. 80 percent of houses have two bedrooms, 13 percent of them have one bedroom and 7 percent of them have more than two bedrooms.

Housing plan: 93 percent of houses do not have a guest room. 21 percent of houses have two yards and all of them have an open kitchen, an indoor lavatory and a bathroom (Table 5).

\section{Identifying the effective factors on rural housing retrofitting}

Table 8 shows the effective factors on villagers' tendency towards retrofitting rural housing. As can be seen, the mean of all items is more than 4 except the item of "the extent of education in order to promote villagers' technical knowledge" which its mean is less than 4 (3.73\%). The highest mean relates to the item of "the extent of focusing on the bed and kind of soil at the time of building the house" $(4.86 \%)$ and the second place is that of the item of "the extent of supervisors' control over building new houses and/or renovating old ones“"(4.81\%).

Table 3. Validity and reliability of the variables based on Cronbach alpha

\begin{tabular}{|c|c|c|c|}
\hline Index & Items & Number of items & Cronbach alpha \\
\hline Housing retrofitting & $\begin{array}{l}\text { The extent of education in order to promote villagers' technical } \\
\text { knowledge about building houses, the extent of supervisors' con- } \\
\text { trol on building the new houses and/or renovating the old ones }\end{array}$ & 2 & 0.89 \\
\hline $\begin{array}{l}\text { Satisfaction with rural } \\
\text { housing }\end{array}$ & $\begin{array}{c}\text { The extent of families' satisfaction with new patterns of housing } \\
\text { architecture, the extent of families' feeling of safety against the } \\
\text { natural events, the extent of satisfaction with the location of the } \\
\text { house, the extent of satisfaction with the house area and the } \\
\text { number of rooms }\end{array}$ & 4 & 0.82 \\
\hline Housing plan & $\begin{array}{l}\text { Having a guest room, separate bedrooms, two yards, an open } \\
\text { kitchen, having a lavatory inside the house and a bathroom. }\end{array}$ & 6 & 0.68 \\
\hline Independent variables & Age, gender, education & & \\
\hline
\end{tabular}


Table 4. Respondents' descriptive characteristics

\begin{tabular}{|c|c|c|c|}
\hline \multicolumn{2}{|c|}{ Characteristics } & \multirow{2}{*}{$\begin{array}{c}\text { Number } \\
133\end{array}$} & \multirow{2}{*}{$\begin{array}{c}\text { Percent } \\
71\end{array}$} \\
\hline Gondor & Men & & \\
\hline velluet & Women & 53 & 29 \\
\hline \multirow{4}{*}{ Education } & Elementary & 53 & 28.4 \\
\hline & Middle & 25 & 13 \\
\hline & Secondary & 79 & 42.6 \\
\hline & Associate degree or higher & 29 & 16 \\
\hline \multirow{3}{*}{ Ownership type } & Formal document & 18 & 10.2 \\
\hline & Preliminary agreement & 157 & 84.2 \\
\hline & Rental & 11 & 5.6 \\
\hline \multirow{4}{*}{ Occupation } & Farmer & 88 & 47.3 \\
\hline & Worker & 54 & 29.03 \\
\hline & Housewife & 15 & 8 \\
\hline & Others & 29 & 16 \\
\hline \multirow{2}{*}{ Building age } & $1-5$ years & 155 & 83 \\
\hline & 6-10 years & 31 & 17 \\
\hline \multirow{2}{*}{ Building quality } & In-building & 15 & 8 \\
\hline & New & 171 & 92 \\
\hline \multirow{2}{*}{ Number of family in a residential unit } & Single-family & 155 & 83 \\
\hline & Two-family & 31 & 17 \\
\hline
\end{tabular}

Source: Research Findings, 2019

Table 5. Housing plan in studied villages

\begin{tabular}{ccc}
\hline Items & Yes & No \\
\hline Having a guest room & 7 & 93 \\
Having separate rooms as bedrooms & 100 & - \\
Having two yards & 21 & - \\
Having an open kitchen & 100 & - \\
Having an indoor lavatory & 100 & - \\
Having a bathroom & 100 \\
\hline Source: Research Findings, 2019 & &
\end{tabular}

Table 6. Paid facilities statistics (in Rials) in terms of the stage of facilities in Jahrom County during 2005-2011

\begin{tabular}{ccccc}
\hline Total & Third stage & Second stage & First stage & Year \\
\hline 20930000000 & 3894000000 & 10592000000 & 6444000000 & 2005 \\
\hline 28625700000 & 4016580000 & 15697720000 & 8911400000 & 2006 \\
\hline 46517000000 & 6189000000 & 21209000000 & 19119000000 & 2007 \\
\hline 54348000000 & 7689000000 & 33113000000 & 13546000000 & 2008 \\
\hline 76866000000 & 29688000000 & 23868000000 & 23310000000 & 2009 \\
149039000000 & 55840000000 & 45990000000 & 47209000000 & 2010 \\
\hline 16340000000 & 2940000000 & 5610000000 & 7790000000 & 2011 \\
\hline Source: Islamic Republic Housing Association of Jahrom County, 2018. & & & JSRD \\
\hline
\end{tabular}


Table 7. Collective statistics of building units' number in terms of the stage of records in Jahrom County during 2005-2011

\begin{tabular}{rcccccccc}
\hline Total & Completion & $\begin{array}{c}\text { Third } \\
\text { stage }\end{array}$ & $\begin{array}{c}\text { Second } \\
\text { stage }\end{array}$ & $\begin{array}{c}\text { First } \\
\text { stage }\end{array}$ & Conclusion & Presentation & Registration & Year \\
\hline 3133 & 412 & 412 & 418 & 423 & 440 & 511 & 517 & 2005 \\
\hline 3737 & 497 & 497 & 504 & 511 & 526 & 576 & 626 & 2006 \\
\hline 5405 & 712 & 712 & 715 & 717 & 740 & 892 & 917 & 2007 \\
\hline 5370 & 721 & 722 & 726 & 727 & 757 & 851 & 866 & 2008 \\
\hline 5470 & 739 & 776 & 776 & 784 & 784 & 795 & 816 & 2009 \\
\hline 10832 & 1291 & 1459 & 1533 & 1594 & 1632 & 1641 & 1682 & 2010 \\
\hline 1806 & 33 & 85 & 147 & 203 & 257 & 522 & 559 & 2011 \\
\hline Source: Islamic Republic Housing Association of Jahrom County, 2018. & & & & J J \\
\hline
\end{tabular}

Table 8. The effective factors on villagers' tendency to retrofitting rural housing

\begin{tabular}{|c|c|c|c|c|}
\hline \multirow[b]{2}{*}{ Items } & \multicolumn{4}{|c|}{ Frequency and significance level } \\
\hline & Mean & $\begin{array}{l}\text { Standard devia- } \\
\text { tion }\end{array}$ & $\begin{array}{l}\text { Chi- } \\
\text { Square }\end{array}$ & Sig. level \\
\hline $\begin{array}{l}\text { The extent of families' satisfaction with new patterns of housing } \\
\text { architecture }\end{array}$ & 4 & 0.519 & 132.484 & 0.000 \\
\hline The extent of families' feeling of safety against natural events & 4.59 & 1.214 & 117.763 & 0.000 \\
\hline The extent of satisfaction with the location of the house & 4.59 & 1.214 & 117.763 & 0.000 \\
\hline The extent of satisfaction with the area and number of rooms & 4.596 & 0.715 & 132.484 & 0.000 \\
\hline The extent of consulting with engineers at the time of building & 4.655 & 0.756 & 80.022 & 0.000 \\
\hline $\begin{array}{l}\text { The extent of education in order to promote villagers' technical } \\
\text { knowledge }\end{array}$ & 3.73 & 0.444 & 39.763 & 0.000 \\
\hline $\begin{array}{c}\text { The extent of considering the bed and kind of soil at the time of } \\
\text { building }\end{array}$ & 4.86 & 0.511 & 137.634 & 0.000 \\
\hline $\begin{array}{l}\text { The extent of supervisors' control over building a new house and/ } \\
\text { or renovating old ones }\end{array}$ & 4.81 & 0.577 & 124.215 & 0.000 \\
\hline
\end{tabular}

The most important reasons for the tendency to retrofitting housing

According to respondents, the most important reason for the tendency to retrofitting housing in the studied villages is the use of rural housing facilities $(67 \%)$, while 37 percent of respondents reported that they retrofitted their homes because of safety against natural disasters such as floods and earthquakes (Table 9).

According to Table 11, we can say that since the highest frequency relates to "receiving facilities" and its sig- nificance level is less than 0.05 , thus, the above hypothesis is confirmed.

Independent variables and tendency to retrofitting

Gender and tendency to housing retrofitting- We used a t-test for examining this hypothesis. The results of Table 12 show that based on our means (4.3 and 4.5) and significance level, there is not any difference between men and women in the tendency towards retrofitting housing.

Table 9. The most important reasons for the tendency to retrofitting housing

\begin{tabular}{rc}
\hline Most important reasons & Percentage \\
\hline Use of rural housing facilities & 67 \\
Safety against natural disasters & 33 \\
\hline Source: Research Findings, 2019 & O JSRD
\end{tabular}


Table 10. The observed and expected frequencies

\begin{tabular}{cccc}
\hline Explanation & Observed frequency & Expected frequency & Result \\
\hline Use of rural housing facilities & 130 & 93 & 37 \\
Safety against natural disasters & 56 & 93 & -37 \\
Total & 186 & & \\
\hline
\end{tabular}

Source: Research Findings, 2019

JSRD

Table 11. Chi-square testing

\begin{tabular}{cc}
\hline Facilities & \\
\hline Chi-square & 29.441 \\
Degree of freedom & 1 \\
significance & 0.000 \\
\hline
\end{tabular}

Source: Research Findings, 2019

( JSRD

Table 12. Number, mean and standard deviation of research sample volume

\begin{tabular}{cccccc}
\hline Explain & Gender & Number & Mean & Standard deviation & Mean deviation error \\
\hline \multirow{2}{*}{ Housing retrofitting } & Men & 130 & 4.3077 & 1.07000 & 0.09385 \\
& Women & 50 & 4.5200 & 0.95276 & 0.13474 \\
\hline
\end{tabular}

Source: Research Findings, 2019

Table 13. Mean difference testing

\begin{tabular}{|c|c|c|c|c|c|c|c|c|c|}
\hline \multirow{3}{*}{ Explanation } & \multicolumn{4}{|c|}{$\begin{array}{l}\text { t-test for testing quality of } \\
\text { variances }\end{array}$} & \multicolumn{3}{|c|}{ t-test for Equality of Means } & & \\
\hline & \multirow[t]{2}{*}{ f- statistics } & \multirow{2}{*}{$\begin{array}{c}\text { Significance } \\
\text { level }\end{array}$} & \multirow[t]{2}{*}{ t-statistics } & \multirow{2}{*}{$\begin{array}{l}\text { Degree of } \\
\text { freedom }\end{array}$} & \multirow{2}{*}{$\begin{array}{c}\text { Sig. } \\
\text { (2-taile) }\end{array}$} & \multirow{2}{*}{$\begin{array}{l}\text { Mean Dif- } \\
\text { ference }\end{array}$} & \multirow{2}{*}{$\begin{array}{l}\text { Std. Error } \\
\text { Difference }\end{array}$} & \multicolumn{2}{|c|}{$\begin{array}{l}\text { 95\% confidence Inter } \\
\text { val of difference }\end{array}$} \\
\hline & & & & & & & & Lower & Higher \\
\hline $\begin{array}{l}\text { Equal variance is } \\
\text { given }\end{array}$ & 3.364 & 0.068 & -1.228 & 178 & 0.221 & -0.2123 & 0.17291 & -0.55352 & 0.12891 \\
\hline $\begin{array}{l}\text { Equal variance is } \\
\text { not given }\end{array}$ & -- & -- & -1.293 & 99.203 & 0.199 & -0.2123 & 0.16420 & -0.53811 & 0.11349 \\
\hline
\end{tabular}

Age and tendency to housing retrofitting- We used the Pearson test for examining this hypothesis. According to Table 14, since the significance level is more than 0.05 $(\mathrm{Sig}=0.252)$, the relation between the variable "age" and housing retrofitting is not supported.

Education and tendency to housing retrofitting- We used the Pearson test for examining this hypothesis. Since our significance level is more than 0.05 ( $\mathrm{Sig}=0.085)$, the relation between education and housing retrofitting is not supported (Table 15).
Analyzing the effective factors on rural housing retrofitting from the viewpoint of villagers by using Factor Analysis

We factorized the research variables by using SPSS software and a developed statistical method: Factor Analysis. Accordingly, those indices which are internally related prefer to group around an axis or factor; so, indices with a negative correlation cannot make a group with the indices form another factor. Thus, our factors are extracted from the correlation matrix. In this research, we studied the effective factors on rural housing retrofitting with seven initial items, and reduced these indices 
to two factors by the "Varimax" rotation method. The sum of four factors cover 78.289 percent of the variance. Thiswas presented combined with significant factors and the percentage of each factor was determined in housing status. In this calculation, all values less than 0.5 , which are coded in Matrix F, were omitted. Since the special value of the standardized variance is a mean of 0 and a standard deviation of 1 , if the variance of a standardized index which leads to extract the main components equals 1 , it is a component with a special value less than 1 which its significance is less than the observed index. Therefore, we can neglect it. Thus, we omitted all factors with a special value less than 1 .

Since the results of the KMO test are more than 0.5 (Table 16) and the significance level (0.00) with the probability of over 99 percent supports that there is a correlation between variables, this matrix is appropriate for the next analyses.

Table 14. Relation between age and housing retrofitting
Factors Naming- As seen in Table 17, the result of factor analysis was reducing of the seven initial variables to 2 superior factors by Varimax rotation. The variance of 78.289 percent shows that the results of factor analysis are satisfactory and this matrix is appropriate for the next analyses. Regarding the extent of correlation of each index, we can select appropriate names for them.

The first factor- The special value of this factor is 4.5 , which can calculate and determine 57.45 percent of the variance. In this factor, four variables were coded which have the most effect between the two factors: the extent of satisfaction with the new pattern of housing architecture, the extent of familis' feeling of safety against natural events, the extent of satisfaction with the location of the house, and the extent of satisfaction with the area and number of rooms. Grouping of these variables in one factor shows a high correlation between them. Therefore, based on the grouped variables, we can name this factor "satisfaction with rural housing" (Table 18).

\begin{tabular}{ccc}
\hline Explanation & Age & Retrofitting \\
\hline Pearson correlation & 1 & -0.050 \\
Significance level Age & 0 & 0.252 \\
Number & 186 & 186 \\
Pearson correlation Retrofitting & -0.050 & 1 \\
Significance level & 0.252 & 0 \\
Number & 186 & 186 \\
\hline
\end{tabular}

Source: Research Findings, 2019

JSRD

Table 15. Relation between education and housing retrofitting

\begin{tabular}{|c|c|c|}
\hline Explanation & Education & Retrofitting \\
\hline $\begin{array}{c}\text { Pearson correlation Education } \\
\text { Significance level }\end{array}$ & $\begin{array}{l}1 \\
0\end{array}$ & $\begin{array}{l}0.129 \\
0.085\end{array}$ \\
\hline Number & 186 & 186 \\
\hline $\begin{array}{c}\text { Pearson correlation } \\
\text { Significance level }\end{array}$ & $\begin{array}{l}0.129 \\
0.085\end{array}$ & $\begin{array}{l}1 \\
0\end{array}$ \\
\hline Number & 186 & 186 \\
\hline
\end{tabular}

Source: Research Findings, 2019

JSRD

Table 16. KMO and Bartlett Tests

\begin{tabular}{ccc}
\hline & KMO & 0.627 \\
Bartlett Test & Chi-square & 481.659 \\
& Degree of freedom & 45 \\
\hline Source: Research Findings, 2019 & Significance & 0.000 \\
\hline
\end{tabular}


Table 17. The final extracted factors and related values

\begin{tabular}{cccc}
\hline Factor & Special value & Variance percentage & Collective variance percentage \\
\hline 1 & 4.596 & 57.455 & 57.455 \\
2 & 1.667 & 20.835 & 78.289 \\
\hline
\end{tabular}

Source: Research Findings, 2019

Table 18. The coded indices in the first factor

\begin{tabular}{cccc}
\hline & & Index & Correlation \\
\hline 1 & The extent of satisfaction with the new pattern of housing architecture & 0.815 \\
2 & The extent of families' feeling of safety against natural events & 0.724 & 0.712 \\
3 & The extent of satisfaction with the location of the house & 0.689 \\
4 & The extent of satisfaction with the area and number of rooms & Housing \\
\hline
\end{tabular}

Source: Research Findings, 2019

The second factor- According to Table 19, the special value of this factor is 1.66 which can calculate 20.83 percent of variance. In this factor, three variables were coded: the extent of education in order to promote villagers' technical knowledge about building the house, the extent of focusing on the bed and kind of soil at the time of building, and the extent of supervisors' control over building the new houses or renovating the old ones. Based on the coded variables, we can name this factor "housing stability".

\section{Discussion}

One of the most important rural needs is rural housing. Rural housing procurement is usually one of the impor- tant elements of different development plans. Housing as a necessary need and one of the major elements of skeletal context of houses has a main role in forming rural spatial structure and the most important criterion for satisfaction with housing relates to its stability. Given the instability of the country's' geographical scene in terms of earthquakes, rural homes are more vulnerable to earthquakes due to some reasons such as non-observance of technical regulations, use of traditional building materials and instability of houses. In recent years, rural housing loan policy has been done and the government has tried to support rural housing renovation by paying housing loans. In other words, rural housing retrofitting is a strategy for reducing human casualties and economic damages in rural regions.

Table 19. The coded variables in the second factor

\begin{tabular}{cccc}
\hline & Index & Correlation & Factor's Name \\
\hline 1 & $\begin{array}{c}\text { The extent of education in order to promote villagers' technical } \\
\text { knowledge about building the house }\end{array}$ & 0.683 & Housing \\
Stability
\end{tabular}

Source: Research Findings, 2019

- JSRD

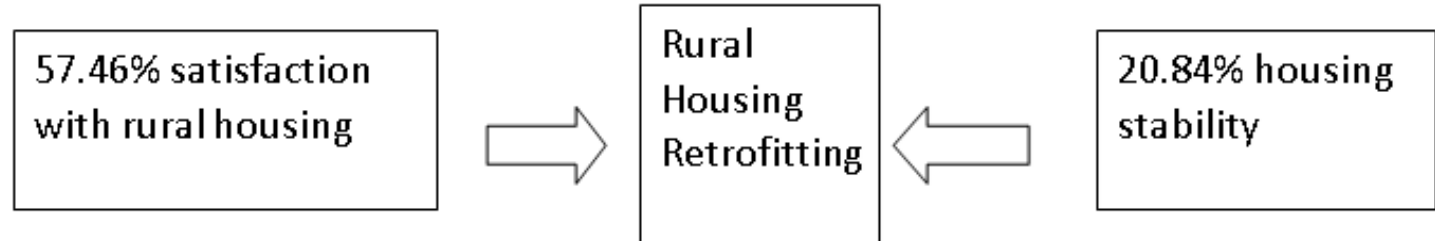

Figure 2. Examining the effects of factors on rural housing retrofitting with the percentage of each 
Thus, we examined the effective factors on villagers' tendency to rural housing retrofitting in Simekan District, Jahrom County, and the following results were obtained:

We factorized the research variables by using SPSS software and a developed statistical method, factor analysis. In the present research, we studied the effective factors on rural housing retrofitting with seven initial items, and reduced these indices to two factors by the "Varimax rotation" method.

The sum of two factors covers 78.23 percent of the variance. It was also found that the first factor (satisfaction with rural housing) accounts for 57.45 percent of the variance and the second factor (housing stability) accounts for 20.84 percent of the variance. It was also found that the most important reason for retrofitting rural housing is the use of rural housing facilities (67\%), while safety against natural disasters such as floods and earthquakes $(33 \%)$ is another reason for retrofitting housing. Therefore, the main hypothesis is supported. According to the results of hypothesis testing, Pearson correlation coefficient, variance testing and significance value which is more than 0.05 , there is no significant difference between independent variables (gender, age, education) and housing retrofitting.

The results of this paper support the results of previous studies, including Anabestani et.al. (2012), Rahmani Fazli and Kavyani (2009), Karimi Azar and Shamsi Yousefi (2009), Motiee Langerudi and Bakhshi (2010) and Azimi et.al. (2014). In addition, the results are consistent with the results of the studies conducted by Mohammadi Yeganeh et al. (2017), Rabet et al. (2017) and Riahi et al. (2016).

Reducing the problems and impediments for loan applicants, especially economic and financial problems and reducing installments for all villagers, supporting and encouraging the companies responsible for providing and distributing building materials in rural regions, finding the correct location for renovation and adapting materials to the environment, developing infrastructure, developmental foundations, providing services and facilities and reducing poverty in rural areas, detailed explanation of technical regulations for villagers, and focusing on qualitative objectives of retrofitting plans are some strategies for retrofitting rural housing.

\section{Acknowledgements}

This research did not receive any specific grant from funding agencies in the public, commercial, or not-forprofit sectors.

\section{Conflict of Interest}

The authors declared no conflicts of interest.

\section{References}

Afrakhteh, H. \& Havasi, N. (2011). Analysis of the role of housing loans in rural development (case study: rural district of Seyyed Ebrahim Dehloran). Geography Quarterly, 31, 76-55. (In Persian)

Amirahmadi, H. (1992). The combination of earthquake vulnerability reduction and rural development, the physical planning, Proceedings of the Research Center of Planning and Architecture. (In Persian)

Anabestani, A. (2011). The impact of economic activity on rural housing patterns. Case study: Villages of Khorasan Razavi Journal of Engineer Message, 54, 101-111. (In Persian)

Anabestani, A. (2014). analyzing the impact of social change in the lives of the villagers on the pattern of rural housing (Case study: Binaloud County). Journal of Research and Rural Planning, 3(5), 57-68. (In Persian)

Anabestani, A., Shayan, H, \& Bonyaddasht, A. (2012). surveying the Role of Credits on changing the pattern of housing in rural areas (Case study: Bahmei County). Journal of Spatial Planning, 1(3), 63-80. (In Persian)

Azimi, N., Zali, N. \& Farouqi, M. R. (2014). the effect of rural housing loans in the quality of new residential construction (Case study: Shaft County). Journal of Spatial Planning, 3(12) 127-142. (In Persian)

Bastie, J. \& Dezert, B. (1998). City. Translated by Ali Ashrafi, University of the Arts Publishment, pp. 296, Tehran. (In Persian)

Beiti, H. (2012). Assess the status of local patterns in rural housing construction program (Case study: East Azarbayjan province). Journal of Urban Management, 10(29), 115-130. (In Persian)

Beshaq, M. R., Taqdisi, A. \& Aqa Emraei, A. (2014), Review and evaluating of the sustainability of rural housing, (case study: Malavi rural district in Poldokhtar), Geographic Research Quarterly, no 114, pp. 129-146. (In Persian)

CGAP. (2003). Financial Services for the Rural Poor, Donor Brief, No. 15, October 2003, Washington DC. [Online]: http:/ / www.cgap.org/gm/document-1.9.2394/DonorBrief_15.pdf (In Persian)

Dehqan Farouji, F., Beitolahi, A. \& Nemati, A. (2010). Prioritizing villages of Chahar Mahal and Bakhtiari Based on popula- 
tion density-The first step in the prevention of crisis. Rescue and Help Quarterly, 2(3), 45-59. (In Persian)

Einali, J., Cheraqi, M. \& Roumiani, A. (2014), Assessment of the role of housing credits on the reduction of the physical vulnerability of rural settlements. Case study: BazinehroudKhodabandeh (Zanjan Province) Journal of Housing and Rural Environment, 146, 77-90. (In Persian)

Faezi, S., Elyasi, M., Rafiean Bahabadi, M. (2018). The Impact of Rural Housing Rehabilitation on Rural Landscape (Case Study: Ahmadabad Village of Bahabad County). Journal of Research and Rural Planning, 7(1), 57-79. doi: 10.22067/jrrp. v7i1.63564

Fal Soleiman, M., Hajjipour, M. \& Jamshidi, K. (2013). the vulnerability of structural elements of rural settlements in earthquake-prone areas. Case study: City of Qaenat and Zirkouh Journal of Geographical Space, 6, 75-98. (In Persian)

Farhadi Quliyanlou, M. (2016). Assessing the role of loans for rural housing improvement projects on the texture and architecture of villages using the SWOT analytical model (Case study: Novdeh Village of Boknord County). Journal of Housing \& Rural Environment, 35(153), 73-82. (In Persian)

Ferguson, B. K. (2003). Housing microfinance-a key to improving habitat and the sustainability of microfinance institutions. Enterprise Development \& Microfinance, 14(1), 21-31.

Gallent, N., \& Robinson, S. (2011). Local perspectives on rural housing affordability and implications for the localism agenda in England. Journal of Rural Studies, 27(3), 297-307.

Gallent, N., (2009), Housing Rural. Journal of International Encyclopedia of Human Geography, 7(1), 207-212.

Ghadiri Masoum, M., Bahmani, A., Ghadermarzi, H., Rezvani, M.R. (2021). Evaluation of the effects of a housing renovation special plan on the physical structure and economic performance of rural houses (Case study: eilagh e jonobi village, Dehgolan County). Human Geography Research, 53(1), 4763. doi: 10.22059/jhgr.2019.272204.1007835 (In Persian)

Grameen Bank. (2008). Grameen Bank at a glance. [Online]: http://www.grameen-info.org. -housingmicrofinance.pdf.

Hooman, H. A. (1997). Understanding the scientific method in the behavioral sciences. Tehran, SAMT. (In Persian)

Islamic Revolution Housing Foundation. (2007). A rural housing development report, Tehran. (In Persian)

Islamic Revolution Housing Foundation. (2008). Performance Report 2008, Main Office of Rural Housing. Department of Rehabilitation and Rural Housing, Tehran. (In Persian)

Islamic Revolution Housing Foundation of Jahrom (2014), the number of loans taken by the villagers in the Jahrom County. (In Persian)

Jamshidi, A. R, Jamini, D., Seidaei, S. E. \& Najafi, M. (2013). Analysis of rural housing indexes in Illam and ranking them using Factor analysis and cluster, Housing and Rural Environment, 143, 69-88. (In Persian)

Karimi Azar, A. \& Shamsi Yousefi, A. (2009). Rural housing with an approach to rural housing renovation and retrofit, The first national conference on housing and development of villages, Zahedan, pp. 1-16. (In Persian)
Khan, A. A. (2008). Managing environmental turbulence in the microfinance sector- a case study of the Aga Khan rural support programme in Pakistan, A thesis submitted for Doctor of Philosophy from University of Wollongong, Australia.

Kumar, A. T. \& Newport, J. K. (2007). Microfinance and rural housing- an overview. Published by Indian Association for Savings and Credit (IASC). [online]: http://www.microfinancegateway.org/gm/document-1.9.26771/03.pdf.

Lewis, J. (2003). Housing construction in earthquake-prone places: Perspectives, priorities and projections for development, The Australian Journal of Emergency Management, Vol. 18, No 2. May 2003. Pp: 35-44.

Mahdavinejad, M. J., Pourfathollah, M. \& Mohammadi, F. (2013). The necessity of "family-based" Education for Retrofitting the rural housing, Housing and rural environment, 143, 52-39. (In Persian)

Mohammadi Yegane, B., Cheraqi, M., Abbasi, J. \& Tarasi, Z. (2013). The role of housing improvement funds on improving the quality of rural life. Case study: Zanjan City, Mojezat, Journal of Housing and Rural Environment, 141, 99-108. (In Persian)

Mohammadi Yeganeh, B., Cheraghi, M., Eslami, L. (2017). Analyzing the Effects of Housing-Strengthening Credits on the Sense of Security Among Rural Households (Case Study: Mojezat Rural District, Zanjan County). Physical Development Planning, 4(3), 81-98. (In Persian)

Moteiei Langroudi, S. H. \& Bakhshi, Z. (2010). The role of housing credits on enabling and sustainability of the rural population in Beihaq, Journal of Human Geography Researches, 72, 46-31. (In Persian)

Qadiri Masoum, M. \& Akbarpour Sareskanroud, M. (2011). Analysis of the role of government in rural housing construction in development programs, case study: Fourth plan of country's development. Journal of Geographical Space, 11(34), 74-101. (In Persian)

Qasemi Ardehaei, A. \& Rostamalizadeh, V. (2012). The effects of changes in rural life rural housing loans. Journal of Housing and Rural Environment, 139, 67-84. (In Persian)

Rabet, A., Saiedi, A., Taleshi, M. \& Nazari, A. (2017). The role of housing finance facilities in the renovation and rehabilitation of rural housing (Case study: Ijroud County). Journal of Geographical Space, 17(58), 1-24. (In Persian)

Rahmani Fazli, A. \& Kaviani, Y. (2009). The effectiveness of microcredit in rural housing development. Geography Quarterly, 17(23), 29-45. (In Persian)

Rezvani, M. R. (2011). Rural development planning in Iran, Ghomes Press, Fourth Edition. (In Persian)

Rezvani, M. R., Rastegar, E., Bayat, N. \& Darestan, Kh. (2014) Identifying and analyzing the factors affecting the demand for credit facilities of rural housing with an emphasis on spatial factors. Case study: Settlements of Varavi section, Mehr City, Journal of Housing and Rural Environment, 147, 3-16. (In Persian)

Riahi, V., Parizadi, T., Ghasemi, S. (2016). The Investigation of Bank Loans Role for Housing in Rural Development (Case Study: Rural Areas in Ošnaviya County). Journal of Research and Rural Planning, 5(3), 75-90. doi: 10.22067/jrrp.v5i3.48752 
Saeidi, A. \& Amini, F. (2010). Residential instability and functional evolution of rural housing (Natanz area-Badroud), Geography Quarterly, 8(27), 29-43. (In Persian)

Sartipipour, M. (2010). Evaluation and analysis of rural housing in Sistan and Baluchestan Province and proposing the future orientation. Geography Quarterly, 8(27), 45-60. (In Persian)

Seidaei, S. E. (2010). Spatial analysis of rural housing condition in Kohgiluyeh and Boyer Ahmad Province. Journal of Rural Researches, 1(2), 49-72. (In Persian)

Shakouri, A. \& Asgari, N. (2012). Evaluation of Rural Housing Programs and its impact on the quality of construction in rural areas in the Fourth Development Plan. Case study: Hormozgan Province. Journal of Rural Researches, 3(2), 119-151. (In Persian)

Shamsoddini, A., Shokur, A. \& Rostami, R. (2011). The impact of rural housing renovation on the rural subsistence economy, (case study: central district in Mamseni county). Journal of Housing and Rural Environment, 135, 57-70. (In Persian)

Statistical Center of Iran. (2006). Population and housing census. Tehran: SCI Publication. (In Persian)

Taleb, M., (1993). Sociological View on Rural Credit in Iran. Publisher: Ministry Jahad of Sazandehi. (In Persian)

Young, C. (2007). Housing Microfinance: Designing a Product for the Rural Poor. Centre for Microfinance Working Paper Series No. 19, November 2007. [online]: http://ifmr.ac.in/ cmf/publications/wp/2007/19_young 